Binghamton University

The Open Repository @ Binghamton (The ORB)

\title{
"Indigenismo and Futurism in Latin America: José Carlos Mariátegui and the Peruvian Avant-Garde."
}

Giovanna Montenegro

gmontene@binghamton.edu

Follow this and additional works at: https://orb.binghamton.edu/comparative_literature_fac

Part of the Comparative Literature Commons, and the Latin American Literature Commons

\section{Recommended Citation}

"Indigenismo and Futurism in Latin America: José Carlos Mariátegui and the Peruvian Avant-Garde." International Yearbook of Futurism Studies: Special Issue: Futurism in Latin America. Vol. 7 (2017).

This Article is brought to you for free and open access by the Comparative Literature at The Open Repository @ Binghamton (The ORB). It has been accepted for inclusion in Comparative Literature Faculty Scholarship by an authorized administrator of The Open Repository @ Binghamton (The ORB). For more information, please contact ORB@binghamton.edu. 


\title{
Indigenismo and Futurism in Latin America: José Carlos Mariátegui and the Peruvian Avant-garde
}

\begin{abstract}
This essay explores the encounter between Latin American indigenismo and avant-garde movements such as Futurism through an analysis of avant-garde literary magazines and Peruvian avant-garde poetry with Futurist tendencies. The first section begins with the Amauta magazine (1926-30), edited by the Peruvian Marxist José Carlos Mariátegui (1894-1930), who promoted an indigenous agenda while also censuring and applauding Futurism. The second section briefly investigates the Chilean literary journal Nguillatún (1924), whose founding manifesto toyed with Futurist principles while simultaneously turning to Chile's indigenous culture. In addition, I analyse Gamaliel Churata's Boletín Titikaka (1926-29), which promoted linguistic experimentation with indigenous languages in the form of parole in libertà as a way to reclaim Andean indigenous identity. In the final section, I analyse some Peruvian avant-garde poets who used indigenous, nativist and Futurist themes (especially transportation and technology). While all of these projects applauded the return of the 'autochtone' within the 'national' as a way to promote a 'New-World avant-garde', Futurist, indigenous and nativist themes were not always a compatible mixture. The avant-garde primarily promoted a spirit of innovation in the Peruvian Andes, and also provided a platform from which to promote indigeneity. I argue that Latin American indigenismo allowed for Futurist and avant-garde aesthetics to permeate the social sphere by insisting on social concerns while promoting an international artistic programme.
\end{abstract}

Keywords: Futurist poetry in Peru, indigenismo, nativism, José Carlos Mariátegui, Amauta (1926-30), Nguillatún (1924), Boletín Titikaka (1926-29)

\section{Introduction}

An isthmus, from Ancient Greek: io $\theta \mu$ ó ‘neck', has been defined as "A narrow portion of land, enclosed on each side by water, and connecting two larger bodies of land; a neck of land." ${ }^{1}$ I should like to use this image to guide my explora-

1 "Isthmus" in The Oxford English Dictionary, 2nd edn vol. 8. pp. 139. 


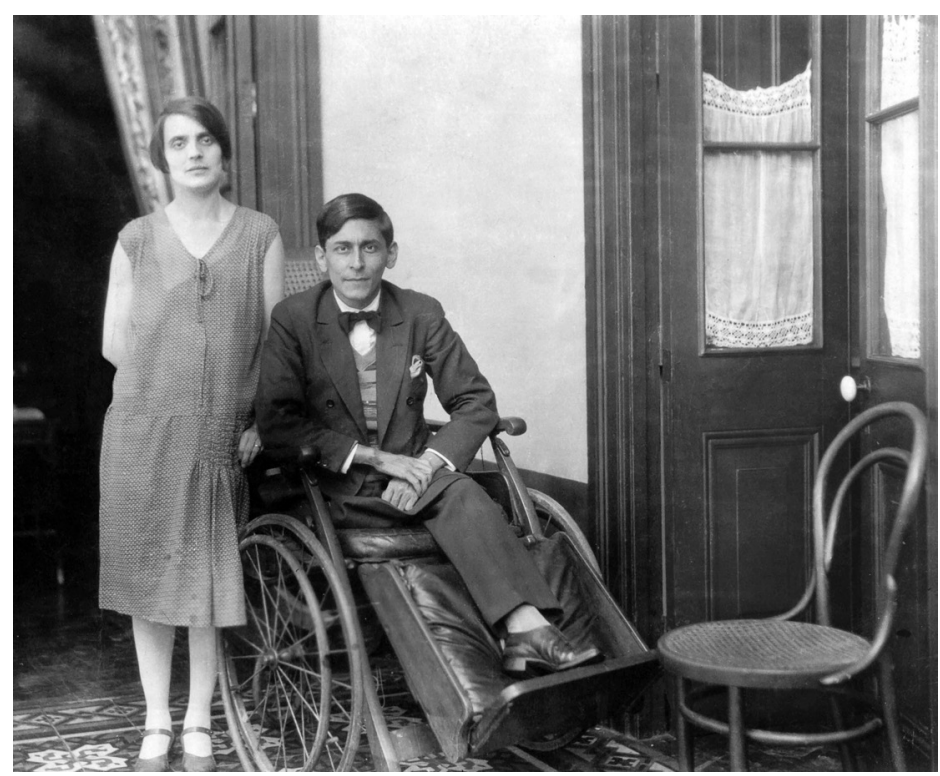

Fig. 1. Portrait of José Carlos Mariátegui with his Italian wife Ana Chiappe in their house in Lima, now the site of the Casa Mariátegui.

tion of the connections between Futurism and Latin American indigenismo. ${ }^{2}$ The discussion on Futurism and other avant-garde movements in Latin America has generally centred on Europe's creative influence over Latin American artists and writers. ${ }^{3}$ Yet critics have responded to this by emphasizing that the Latin American avant-garde responded to modernization and transculturation by means of region-specific aesthetic and social forms. ${ }^{4}$ In this essay, I explore the work of those who bridged indigenous and mestizo ${ }^{5}$ culture through the isthmus of the avant-garde. Ideologically, the isthmus of the avant-garde functioned as a metaphorical space through which social and aesthetic pro-indigenous goals were

2 Indigenismo is a political ideology that promotes the social and political inclusion of indigenous populations of the Americas. In particular, it emphasizes the relationship between the State and its often minority indigenous populations, sometimes through a nostalgic return to folkloric practices.

3 See Osorio Tejeda: Manifiestos, proclamas y polémicas de la vanguardia literaria hispanoamericana, as well as his El futurismo y la vanguardia literaria en América Latina.

4 See Vich: Indigenismo de vanguardia en el Perú and Videla de Rivero: Direcciones del vanguardismo hispanoamericano.

5 Mestizo denotes a person of combined European and Amerindian descent. 
filtered, mediated and processed to make them palatable for a predominantly mestizo audience, who usually lived far away from the indigenous population in the Andes mountain range. My aim is to show how indigenismo functioned in a Futurist fashion; rather than study the impact of Futurism and the European avant-garde on Andean indigenous and mestizo groups, I argue that Latin American indigenismo allowed Futurism to permeate the social sphere through its focus on both local social concerns as well as the promotion of an international artistic programme.

\section{José Carlos Mariátegui and the Latin American avant-garde}

In Direcciones de vanguardismo hispanoamericano (Directions of the Hispanoamerican Spanish American Avant-garde, 1990), Gloria Videla de Rivero reviewed the fractured nature of Latin American vanguard movements as compared to their European counterparts. Although critics acknowledged that a synthesis of Latin American and European models resulted in innovative developments, the identities of the various '-isms' such as Futurism and Surrealism and their Latin American equivalents were ultimately seen as copies of their European 'originals'. ${ }^{6}$ Latin American vanguard movements such as Martinfierrism, Atalayism, Diepalism and Euphorism created original schools that sought to balance aesthetic innovation and socio-political concerns in their works of art. ${ }^{7}$ As Videla de Rivero maintains, one of the main tenets of the Latin American vanguards was their preoccupation with the future: "The vanguard artists want to organize that which is to come, to inaugurate a new era, change courses, contribute to 'progress' (formal research, experimentation, incorporation of new anti-conventional themes and tones)."

This preoccupation with both the future and social concerns forged the cultural and temporal connections between indigenismo and Futurism. The Peruvian Marxist intellectual José Carlos Mariátegui (1894-1930), author of Siete ensayos de interpretación de la realidad peruana (Seven Interpretive Essays on Peruvian Reality, 1928) and the founder and editor of the magazine Amauta (1926-30), was one of the main proponents of indigenismo and an artistic avant-garde of Peru. He sought to address the social legacy of the avant-garde within the context of social

6 Videla de Rivero: Direcciones del vanguardismo hispanoamericano (1st. edn), p. 24. For a case study of 'copycat' claims in Venezuela's avant-garde groups, see also Montenegro: "Futurism in Venezuela: Arturo Uslar Pietri and the Reviews 'Índice' and 'Válvula'.”

7 Videla de Rivero: Direcciones del vanguardismo hispanoamericano (1st. edn), p. 25. 
justice and civil rights of the indigenous population. Mariátegui was born to an impoverished mestiza mother in the Peruvian town of Moquegua. As a teenager, he worked on menial jobs for Lima newspapers and published short pieces under the pseudonym 'Juan Croniqueur'. He became recognized for his sharp political observations and worked his way up to become a journalist for La prensa (The Press,1914-16), the magazine Mundo limeño (The World of Lima, 1917-?) and the newspaper El tiempo (The Times, 1916-19), which he left to found the socialist La razón (The Reason, 1919). Facing the risk of a prison sentence at the hands of Augusto B. Leguía's repressive government, Mariátegui was exiled to Europe as a foreign correspondent of El tiempo and ended up in Italy, where he married the Italian Ana Chiappe. In Italy, he witnessed the Turin factory occupations in 1920 and saw the rise of Benito Mussolini's Fasci di combattimento and the PNF. ${ }^{8} \mathrm{He}$ became familiar with Filippo Tommaso Marinetti's Futurist movement and in 1921 wrote "Aspectos viejos y nuevos del futurismo" (Old and New Aspects of Futurism). ${ }^{9}$ The article, which examined the creative 'old' aspects of Futurism vs. its 'new' political tendencies, maintained: "Futurism is the Italian manifestation of the artistic revolution which in other countries has come up under the name of Cubism, Expressionism and Dadaism." ${ }^{10}$ His conflation of many avant-garde movements tended towards the explanatory. Yet his tone quickly deteriorates as he criticises Marinetti's and the movement's politics: “And the political programme of Futurism was false, literary and artificial. And it can’t even be legitimately called Futurist because it was saturated with conservative sentiments despite its revolutionary rhetoric. In addition, it possessed a local, an essentially Italian agenda."11

Despite Mariátegui’s misgivings about Futurism's limited relevance and reactionary political direction, he believed that it was the first avant-garde movement to arrive in Peru. ${ }^{12}$ In 1924 he published an essay on Marinetti and Futurism ${ }^{13}$ that

\footnotetext{
8 See the volume edited by Podestá: Mariátegui en Italia.

9 Dated 'Rome, April, 1920', it was published on 3 August 1921 in El tiempo (Lima). See Castrillón Vizcarra: "José Carlos Mariátegui, crítico de arte".

10 “El 'futurismo' es la manifestación italiana de la revolución artística que en otros países se ha manifestado bajo el título de cubismo, expresionismo, dadaísmo”. Mariátegui: “Aspectos viejos y nuevos del futurismo", p. 221.

11 "Y falso, literario y artificial era el programa político del futurismo. Y ni siquiera podía llamarse, legítimamente, futurista, porque estaba saturado de sentimiento conservador, malgrado su retórica revolucionaria. Además, era un programa local. Un programa esencialmente italiano.” Mariátegui: “Aspectos viejos y nuevos del futurismo”, p. 222.

12 Mojarro Romero: "Mariátegui y el futurismo italiano", s.p.

13 Mariátegui: "Marinetti y el futurismo". Mariátegui first published this essay in Variedades (Lima) on 19 January 1924 and then included it in his book, La escena contemporánea (1925).
} 
continued to criticize the movement and the 'Duce', as he called Marinetti. He had many complaints; amongst them were the following: ${ }^{14}$

1. He criticized Futurism for not having its own artistic programme and instead for borrowing from other artistic movements.

2. More than a new art, Futurism represented the destruction of the old, and it tried to become a movement for political renewal.

3. Futurism's international ambitions had been quelled - it became quintessentially Italian.

4. Futurism's imperialist political programme was also reactionary rather than revolutionary.

5. Futurism promoted war.

6. Marinetti's Futurismo e fascismo (1924) exemplified Marinetti's attempt to build an 'artocracy' of Futurists within Fascism.

Although Mariátegui considered Marinetti "uno de los personajes más interesantes y originales del mundo occidental" (one of the most interesting and original personalities world-wide), ${ }^{15}$ he reacted against his politics and erroneously saw in Fascism the only political affiliation of Italian Futurists. ${ }^{16}$ He pointed to Futurist writers Emilio Settimelli and Mario Carli, who edited the daily newspaper L'impero (Empire) and L'impero d'Italia (The Italian Empire) in Rome, as examples of the reactionary and Fascist turn of Futurism. ${ }^{17}$ Between 1924 and 1930, Mariátegui's continued conflation of Futurism and Fascism reveals that he was unaware of the Fascist régime's persecution of Italian Futurists including Settimelli and Marinetti. Mariátegui's comments on the links between Futurism and Fascism beg for closer scrutiny, as he did not understand the complexities of

14 See also Ayala: "Mariátegui, el fascismo y futurismo”, pp. 9-11.

15 Mariátegui: "Marinetti y el futurismo", p. 187.

16 See also Sylvers: "La formación de un revolucionario", pp. 44-45. Sylvers discusses Mariátegui's essays on Gabrielle D’Annunzio and Marinetti and their connection to Fascism. Mariátegui stated that Fascism was D’Annunzian; yet Mariátegui saw Fascism as becoming a reactionary political movement, which eventually forced Marinetti to give up his iconoclastic attitude and violent anticlericalism because of the alliance between Fascism, the monarchy, and the Catholic Church, p. 45.

17 See Berghaus: Futurism and Politics, pp. 158; 230; 219; 265. Berghaus gives an example of Settimelli as a "Fascist dissident" who was expelled from the Fascist party and the Syndicate of Journalists and put on trial before the Special Tribunal for the Defence of the State, p. 230. Roberto Farinacci, a leading and authoritarian Fascist leader and politician, had a vendetta against him and asked Mussolini in 1933 to not hinder his campaign against him. Mario Carli also ended up becoming a political dissident, although he worked as an Italian diplomat in Porto Alegre in Brazil. 
Italian Futurism's politics, as Günter Berghaus demonstrated in his Futurism and Politics (1996), which ranged from an attachment to the radical left, Futurists' participation in the Fasci di Combattimento, the reluctant coexistence of Fascism and Futurism, as well as active Futurist resistance against the Fascist régime. Six years later, in his El balance del suprarrealismo (A Balance Sheet on Surrealism, 1930), Mariátegui again wrote about his opposition to Futurism, because of its members supported Fascism.

The Futurist Italian was, without doubt, certainly an exception to the rule. Marinetti and his henchmen intended to represent not only artistically, but also politically and sentimentally, a new Italy. But the Futurist when viewed from a distance, makes us smile this side of his histrionic megalomania; perhaps more than any other he has entered the "order" and the academy: Fascism has digested him effortlessly, which does not credit the assimilative power of the Black Shirts regime, but rather the innocence of the Futurists. Futurism has also, to some extent, the virtue of persistence. But, in this respect, the Futurist's was a case of longevity, not continuity or development. In each recurrence, one recognizes the old prewar Futurism. The wig, makeup, tricks, did not prevent one from noticing the cracked voice, the mechanized gestures. Marinetti, unable to obtain a continuous dialectic presence of Futurism in Italian literature and Italian history, saves it from being forgotten through noisy rentrées. Futurism, in the end was certainly flawed by its so-Italian affinity for the spectacular, the histrionic, and perhaps that would be the excuse an honest critical review could concede, condemning Marinetti to a life behind the proscenium, in an entrancing, fictional, declamatory role. The fact that one cannot speak of Futurism without the use of theatrical terminology confirms this dominant feature of its character. Surrealism has another kind of life. It is truly a movimiento, an experiencia. ${ }^{18}$

According to Mariátegui, Marinetti failed to create a 'new Italy', yet, he excelled at persistence, longevity and noisy and theatrical 'rentrées'. Compared to Mexican Stridentism, which cherished the uproar and clamour of the avant-garde, Mariátegui disapproved of Futurism's theatricality and demanded a more artistic and socially conscious movement. Mariátegui did applaud Futurism's progressive stance, which he used in his vision of a 'New Peru', yet he appreciated the pronounced left-wing direction of Surrealism more. ${ }^{19}$ If anything, the passage cited above seeks to explain how Fascism 'digested' Futurism. In a sense, Mariátegui cast Futurism aside as Marinetti continued to fight, with his 'rentrées', for recognition of his movement from the Fascist establishment. Mariátegui had lived in Italy from 1919-1923. He associated Italian Futurism with the figure of Marinetti, and as such, his critique of Futurism did not take into consideration the

18 Mariátegui: “A Balance Sheet on Surrealism”, pp. 415-416.

19 Gallo: “Wireless Modernity: Mexican Estridentistas, Italian and Russian Futurism”, pp. 142143. 
many anti-Fascists and a-Fascist artists who were part of Futurism's second wave. He also may not have been aware of Futurism's polemical relationship with the Fascist functionaries who regarded the movement as counterrevolutionary. ${ }^{20} \mathrm{He}$ was also unaware of Marinetti's own problematic relationship with Fascism, as the police file opened against him in 1926 shows. ${ }^{21}$

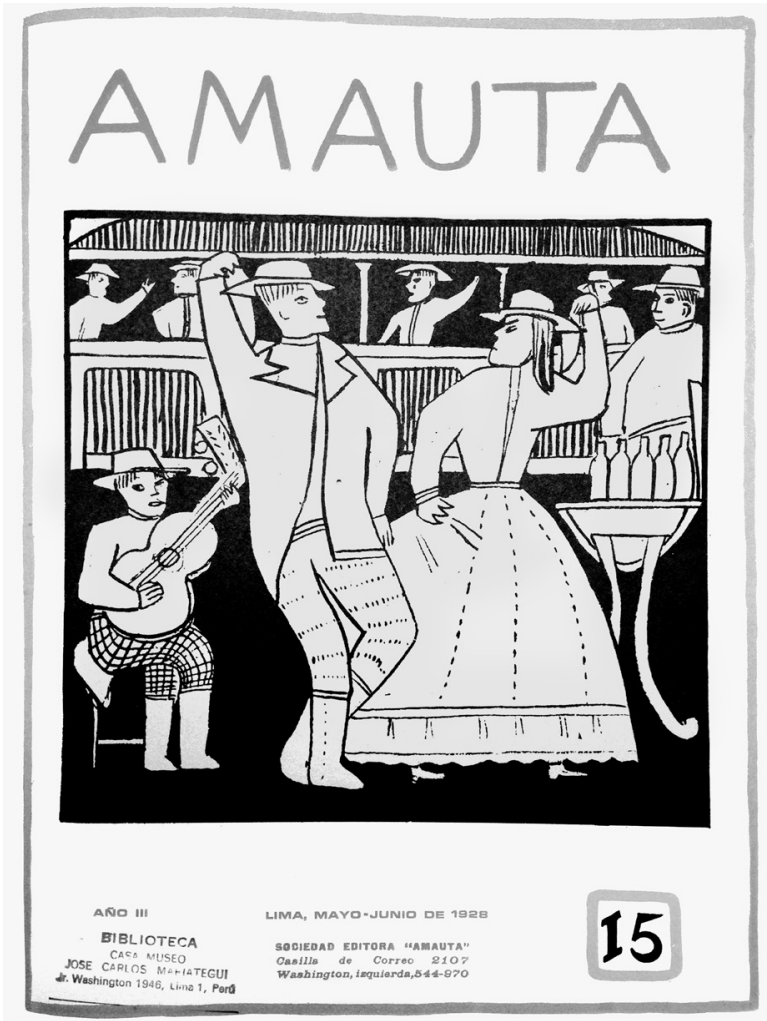

Fig. 2. Amauta vol. 3, no. 15 (May-June 1928). Cover design with indigenist motives.

In his manifesto, Presentación de 'Amauta' (Presentation of “Amauta”, 1926), Mariátegui wrote that he returned to Peru after living in Italy to create an avantgarde magazine in support of the vanguardists, revolutionaries and socialists in Peru. It was a difficult time for Mariátegui personally since, in 1926, he endured

20 Berghaus: Futurism and Politics, pp. 228-229.

21 Berghaus: Futurism and Politics, pp. 281-290. See also Fig. 1 on p. $\square$ of this yearbook. 
illness and a leg amputation before publishing Amauta, a magazine that reflected both the personality and the political, social and aesthetic convictions of its founder. ${ }^{22}$ Amauta aimed to connect the peoples of the Americas and, secondly, Peru with other parts of the world..$^{23}$ As such, Mariátegui created an 'isthmus' of social renewal through his editorial work. Amauta was a periodical that was rooted in the Andes' indigenous cultural legacy (the title Amauta, in the Quechua language, means 'maestro' or 'counsellor ${ }^{24}$ ). The use of Quechua as an "homage towards Incaism" 25 in the magazine's title shows the esteem Mariátegui had for Peru's indigenous population and its social realities. In fact, the desire to return to the indigenous can also be compared to the European avant-garde's turn to Primitivism, although, in Amauta's case, the return to the indigenous was a way to break with the European colonial model. ${ }^{26}$ Nelson Osorio Tejeda suggests that publications such as Amauta and Revista de avance, published in Havana in 1927-1930, were paradigms of a 'supranational' tendency in early avant-garde magazines of the Americas because of the 'indolence' of their proposals and because of the continental and hemispheric approach in its contributions. ${ }^{27}$ For example, Amauta's use of Incaism relied on local culture, yet it was Pan-American in its desire to connect with artists across the equator as they faced similar social, political and aesthetic struggles. ${ }^{28}$

As Osorio Tejeda explains, events on the European continent of course influenced responses within the Americas; it is no coincidence that after Marinetti's venomous critique of traditionalist Venice, Contro Venezia passatista (Against

22 Schwartz: "Peru”, p. 323.

23 Mariátegui: "Presentación de 'Amauta”, p. 300.

24 See Castrillón Vizcarra: “Iconografía de la revista 'Amauta' ”, p. 36. Castrillón Vizcarra discusses the meaning of the terms 'Incaism' and 'indigenismo' for Mariátegui and his artistic collaborator, José Sabogal. Sabogal was instrumental in helping Mariátegui change the name of the publication from Vanguardia to Amauta. Sabogal, when asked about being an indigenista, answered: "Why, yes, we are cultural indigenistas, because we look for an integral identity with our soil, its humanity and our time.” Castrillón Vizcarra: “Iconografía de la revista 'Amauta” ”, p. 36. 25 Mariátegui: "Presentación de 'Amauta” ”, p. 299. Mariátegui used Incan legacy and history, yet also went beyond this legacy and Spanish colonialism to think about a representation of the Peruvian Indian and of Peru's future.

26 As Krzywkowski writes, there was a link between European Primitivism and indigenismo. Amauta both embraced the European avant-garde, especially through a demand of political and aesthetic renewal. Yet, its turn to indigenismo was a way to also make it an anti-colonial project that embraced the local. See Krzywkowski: “'Amauta', l'Europe et les avant-gardes”, pp. 442-445. 27 Osorio Tejeda: "Prólogo", p. XXXII.

28 For more on Mariátegui’s indigenismo see Casetta: "Il problema indigeno dalla tradizione alla modernità: José Carlos Mariátegui.” 
Past-loving Venice, 1910), many members of the Latin American avant-garde took up the call to fight 'passéism'. Mariátegui's distaste for 'passéism' mirrors Marinetti's and the Latin American avant-garde's in general. In an article called "Pasadismo y futuro" (Traditionalism and the Future, 1924), Mariátegui criticized the conservative orientation of contemporary Peruvian literature that romanticized its Spanish colonial past instead of embracing Peru's Inca history. Yet, most importantly, all Latin American vanguardistas responded to similar anxieties and bonded over the sentiment that they were all united as Americans. ${ }^{29}$

Mariátegui took inspiration from European social reformers in his aesthetic and political reframing of Peru's indigenous legacy. Jorge Mojarro Romero writes that Mariátegui was one of the first to look closely at a revolutionary form of art (Futurism) that depended at times on reactionary politics. ${ }^{30}$ Mariátegui, despite his critical stance on Futurism, published an essay on Giovanni Papini in Variedades, two of Marinetti's manifestos in Amauta ${ }^{31}$ and reproduced a photograph of Marinetti dedicated to Mariátegui. As Jorge Schwartz writes, Mariátegui’s allegiance to Marxism-Leninism did not prevent him from having an open-mind in order to create a new Peru in a new world. ${ }^{32}$ Amauta had more of an international echo than other avant-garde publications from Latin America. Authors such as César Vallejo, Jorge Luis Borges, Filippo Tommaso Marinetti and André Breton were published along with young Peruvian writers such as Xavier Abril, Carlos Oquendo de Amat, Magda Portal etc. ${ }^{33}$ However, it is important to note the political context in which the magazine was published. In the 1920s, Augusto B. Leguía's second presidential term developed into a dictatorial government. He suppressed all forms of opposition and, in 1927, censored Amauta as a Communist publication. It was only after international protests that Mariátegui was able to continue the magazine's publication.

29 Osorio Tejeda: “Prólogo”, pp. XXXII-XXXIII. Osorio Tejeda quotes Mariátegui’s "Pasadismo y futuro" as published in Mundial (Lima, 31 October 1924); however, there seem to be conflicting sources for dates of the original article. The online Biblioteca Amauta edition and the Obras completas cronológicas cite a publication date of 28 November 1924 and the Obras de José Carlos Mariátegui (2014) states 31 October 1924. See Mariátegui: "Pasadismo y futuro”, p. 29.

30 Mojarro Romero: "Mariátegui y el futurismo italiano”, s.p.

31 See Mariátegui: "Giovanni Papini”; Marinetti: "Movimiento futurista.”

32 Schwartz: "Perú: Revistas”, p. 329.

33 Schwartz: "Perú: Revistas", p. 324. 


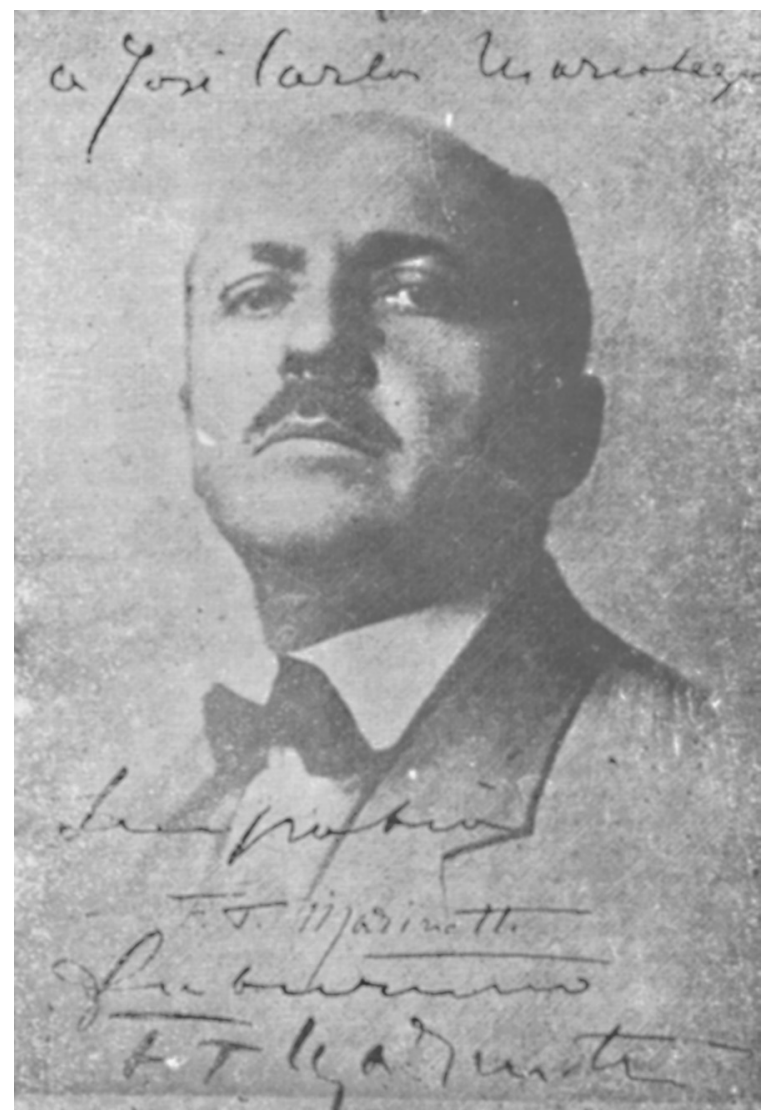

Fig. 3. Photograph of Marinetti with a dedication to Mariátegui, published in Amauta vol. 2, no. 10 (December 1927), p. 29.

Mariátegui's affinity towards Bolshevism and the Russian Revolution made him applaud the Russian Futurists and their social-political agenda. ${ }^{34}$ The avantgarde that he wanted to bring to Peru was based on his interpretation of the Russian model, as can be seen in his essay, "Nativismo e indigenismo en la literatura americana" (Nativism and Indigenism in American Literature, 1927), in which he compares indigenismo in Peru to mujikismo (мужикизм) in Russia: "Muzhikism was bound up with the first phase of social unrest that prepared

34 For more on Mariátegui's assessment of Russian Futurism see his essay, "La nueva literatura rusa”, published in Variedades of 20 March 1926. 
and incubated the Russian revolution. Muzhikist literature performed a historical mission by putting Russian feudalism on trial and condemning it with no possibility of appeal.”35 The muzhik was a male peasant in pre-revolutionary Russia, who figured as a model for the Andean Indian. The Russian serf sought to obtain freedom from feudalism; likewise, Mariátegui imagined that the Peruvian Indian peasant would throw off the chains of colonialism in order to become not only emancipated from a semi-feudal and semi-colonial situation but also become participation in a social and, perhaps, Futurist technological revolution. ${ }^{36}$

As Mariátegui notes, Russian Constructivism and Futurism loved to represent machines, skyscrapers and factories and integrated the peasant in the attempt to westernize Russia, "taking it to a maximum level of industrialism and electrification". ${ }^{37}$ Paradoxically, even though the muzhik had a distinctly anti-Western and anti-Modernist attitude, Mariátegui saw in the peasant an important element in the project of building and modernizing the nation, as well as the great industrialization and electrification process that captured the imagination of Russian Futurists such as Vladimir Mayakovski. In particular, 'Productivism', rooted in Russian Futurism and Constructivism, proved fruitful for Mariátegui. ${ }^{38}$ Mariátegui also saw in the indigenous peoples of the Andes a necessary part of contemporary Peruvian reality:

The indigenism of our contemporary literature is linked to recent developments. If the indigenous problem is part of politics, economics and sociology, it cannot be absent from

35 'El 'mujikismo' tuvo parentesco estrecho con la primera fase de la agitación social en la cual se preparó e incubó la revolución rusa. La literatura 'mujikista' llenó una misión histórica. Constituyó un verdadero proceso del feudalismo ruso, del cual salió este inaplazablemente condenado.” Mariátegui: "El proceso de la literatura. Las corrientes de hoy. El indigenismo", in 7 ensayos de interpretación p. 277. English translation in Mariátegui: "Literature on Trial”, p. 268.

36 Gallo: “Wireless Modernity: Mexican Estridentistas, Italian and Russian Futurism”, pp. 146147. According to Gallo, the Mexican estridentistas also shared with the Italian Futurists "an obsession with modern technology".

37 “[...] llevándola a un grado máximo de industrialismo y electrificación”. Mariátegui: "El proceso de la literatura. Las corrientes de hoy. El indigenismo”, in 7 ensayos de interpretación p. 277. 38 Productivism was an art movement founded by Constructivist artists in post-Revolutionary Russia who believed that art should be practical and socially useful. Bann states that the notion of Productivism came from "art in production", which was associated with Constructivism, but saw its roots in the Russian Futurist movement: "The idea that the artist should control the forms of everyday life was, after all, a logical derivative of the futurist concern with removing the barriers between life and art. As early as December 1918, the literary critic Osip Brik had written in the futurist magazine Iskusstvo kommuny, of which he was editor: 'Go to the factories, this is the only task for artists'.” Bann: The Tradition of Constructivism, p. 21. In particular, Bann cites the work of Alexei Vasilevich Filippov and Alexei Toporkov. See Bann: The Tradition of Constructivism, p. 21. 
literature and art. One would be mistaken to think of it as an artificial issue simply because many of those who advance it are novices or opportunists. ${ }^{39}$

Mariátegui called for indigenismo to act as a guide for a socially responsible form of art in Peru. He believed that criollismo, popular in Argentina, ${ }^{40}$ would fail Peruvians because of the implications of racial miscegenation. Moreover, Mariátegui criticized the nativist tendencies of writers who practiced criollismo because the movement "fed itself on colonial sentiment" and remained tied to Spain in all endeavours. ${ }^{41}$ It is unfortunate that despite his best intentions for the indigenous peoples of Peru, Mariátegui remained racist in his attitudes towards Afro-Peruvians, whom he saw as "primitive", "barbarous" and a remnant of Peru's colonial past. ${ }^{42} \mathrm{He}$ likewise displayed xenophobia towards the Chinese immigrants who had settled around Lima and chastised them for being culturally backward..$^{43}$

Mariátegui's negative views on mestizaje (miscegenation) centred on Lima's criollo and mestizo culture on the coast, which he contrasted with the Indio culture of the highlands. In his view, the Peruvian nation's development hinged upon the unity of its populations. This is why the Indian became such a central figure in his writings: "The Indian does not represent solely a type, a theme, a plot, a character; he represents a people, a race, a tradition, a spirit." ${ }^{44}$ For Mariátegui, the legacy of the indigenous past, as well as the figure of the Indian, were often excluded from discourses that favoured seeing Peru as a mestizo nation. Yet, it was this indigenous legacy that would map out the Futurist path of the Peruvian nation. As Brooke Larson observed:

39 "El indigenismo de nuestra literatura actual no está desconectado de los demás elementos nuevos de esta hora. Por el contrario, se encuentra articulado con ellos. El problema indígena tan presente en la política, la economía y la sociología no puede estar ausente de la literatura y del arte. Se equivocan gravemente quienes juzgándolo por la incipiencia o el oportunismo de pocos o muchos de sus corifeos, lo consideran en conjunto artificioso." Mariátegui: "Nativismo e indigenismo", p. 296. English translation in Mariátegui: "Literature on Trial”, p. 269.

40 Criollismo developed in fin-de-siècle, post-independence Latin America and became a literary and cultural movement in Mexico, Chile and Argentina. The movement upheld regionalist and nationalist interests and saw the rural realm rather than the city as representative of the Nation. Themes such as the struggle against nature and local life prevail.

41 Mariátegui: "Nativismo e indigenismo”, p. 296.

42 Mariátegui: “Literature on Trial”, p. 273.

43 Mariátegui: “Literature on Trial”, p. 279.

44 "El indio no representa únicamente un tipo, un tema, un motivo, un personaje. Representa un pueblo, una raza, una tradición, un espíritu."Mariátegui: "Nativismo e indigenismo", p. 298. Translated in "Literature on Trial", p. 272. 
By the early twentieth century, nationalist rhetoric had constructed a convenient straw man to promote official indigenismo. (Indigenismo, a blanket term for movements claiming to speak for Amerindian interests, in this case refers to a literary and political project promoted by Peruvian intellectuals). In this version of rural reality, Indians became lost souls, victimized by mestizos, entrapped in Feudal estates, and in need of rescuing by the Lima state. ${ }^{45}$

Larson traced the rôles that the Indian played in the construction of the Peruvian nation as tribute-payers, peasants, labourers and soldiers. In late nineteenth-century and early twentieth-century Peru, the Indian shifted from marginal to primary figure; by the time indigenismo emerged, the idea of the Indian was conveniently drafted from the political (and less indigenous) centre, Lima. Mariátegui was also aware of the importance of integrating women's voices into his indigenismo. Equal rights, women's suffrage and participation in the political arena in Soviet Russia were all part of the new development. ${ }^{46}$

Mariátegui's concern for female emancipation coincided with an interest in Alexandra Kollontai, the People's Commissar for Social Welfare and head of the women's department in the Bolshevik Party. ${ }^{47}$ Kollontai became influential for her scathing critique of marriage, which she saw as an extension of ownership of property, and her promotion of a "new eros under communism - a love which extended throughout humanity." 48 She was an instrumental figure for women workers' rights during and after the October Revolution in 1917 and an advocate of women's sexual freedom. Mariátegui held Kollontai in high esteem, while despising consumerism and traditionalist attitudes amongst bourgeois women.

Similarly, Futurism had a department for Women's Action, headed by Valentine de Saint-Point, author of the Manifeste de la femme futuriste / Manifesto della donna futurista (Manifesto of the Futurist Woman, 1912), and the Manifeste futuriste de la luxure / Manifesto futurista della lussuria (Futurist Manifesto of Lust, 1913). ${ }^{49}$ Kollontai, with her high-party position, became a model woman for Mariátegui, yet it is less clear how he envisioned pushing forth a feminist agenda for indigenous women. After all, Kollontai was not a Russian peasant who worked

45 Larson: Trials of Nation Making: Liberalism, Race, and Ethnicity in the Andes, 1810-1910, p. 173. 46 Mariátegui: “Women and Politics”, p. 362.

47 For more on Alexandra Kollontai see Heather Price's Alexandra Kollontai: Soviet Marxist and Feminist; Beatrice Farnsworth's Aleksandra Kollontai: Socialism, Feminism, and the Bolshevik Revolution, and Cathy Porter's Alexandra Kollontai: A Biography.

48 Rowbotham: “Afterword”, in Kollontai: Love of Worker Bees, p. 223.

49 See Contarini: "Valentine de Saint-Point: A Futurist Woman?” Mariátegui did not discuss Saint-Point in any detail and only mentions her manifesto, along with other Futurist manifestos, as a sign of Futurism's embrace of doctrine and dogma. 
in the fields, but rather one of the 'luxury mammals' whom he so despised. It is clear, though, that, much like Saint-Point, he expected gender rôles to change for women, and he demanded the inclusion of women into the literary and political sphere. Amauta, therefore, regularly printed the works of female collaborators such as Magda Portal, the important vanguard Peruvian poet (who would be deported to Cuba for her involvement in Amauta under pretence of being part of a "communist plot"); Carmen Saco, who wrote travel accounts from Moscow and Julia Codesido, an indigenista painter.

\section{Revista Nguillatún and Boletin Tititkaka: The return to the native}

Another Little Magazine that attempted to respond to avant-garde and indigenous concerns was Nguillatún (a Mapuche word referring to a collective religious ritual). Neftalí Agrella (1898-1957), who had met Marinetti in New York, ${ }^{50}$ and Pablo Garrido (1905-1982) founded the magazine in 1924 in Valparaíso, ${ }^{51}$ which was one of the most important centres for the avant-garde in Chile. ${ }^{52}$ According to Osorio Tejeda, "Nguillatún as a project functions as an auto-critical correction of that early cosmopolitanism. Beginning with its name, it seeks an integration with national, popular and indigenous values." 53 The manifesto "Nuestro programa" explains that the group's initial efforts in the Futurist-Creationist avant-garde group Rosa Náutica ${ }^{54}$ were fruitless, since it was rooted in a European framework, rather than focussing on indigenous and national liberation issues. In fact, the group decided to return to Patagonia to embrace Chile's indigenous legacy in their project of literary and artistic renewal. That is how Nguillatún countered the criticism that Latin American vanguardism only 'copied' the European avantgarde movements:

And because on another occasion we were labelled 'Eurocentric' and 'servile', for the reason that we simply cited a few triumphant artistic theories and formulas from Europe, there's

50 Scholz: "Julio Walton H.: El aullido de las rameras. Un texto inédito del grupo 'Rosa Náutica”, p. 173.

51 While in this essay I focus mostly on indigenismo and Futurism in Peru, the example of Nguillatún's manifesto shows how widely avant-garde artists were relating this and similar issues to the notions of the 'national'.

52 See [Anon.]: “Nuestro programa: ‘Revista Nguillatún”, p. 151.

53 [Anon.]: “Nuestro programa: 'Revista Nguillatún”, p. 151.

54 See Scholz: “Julio Walton H.: El aullido de las rameras”, pp. 173-178 and Yurkievich: "Rosa Náutica, un manifiesto del movimiento de vanguardia chileno." 
nothing more efficient to correct new misunderstandings than to start afresh from where we first set out. This new form is, of course, rooted in our race. ${ }^{55}$

Nguillatún's reaction against charges of 'copycat' activity made the group reflect upon Chile's own indigenous cultural legacy. Their association with an indigenous identity, "nuestra raza", became the grounds on which they promoted a Chilean national identity. The group's promotion of the 'antipode'56 may be interpreted as a North-centric image of inhabitants from the Southern hemisphere. However, they wanted to promote a national image and, in this way, spoke about an arte nacionalista (nationalist art), nación joven (young nation), una disciplina mental nacionalista (a nationalist mental discipline) and otras naciones (other nations), identifying their own uniqueness vis-à-vis "other antipode intellectual zones". ${ }^{57}$

In Nguillatún's manifesto, the editors promoted indigenous culture and an anthropological and ethnographic view of folk culture. Primitivism permeates the group's love of the aboriginal, fetish objects, primitive sculpture and adornments. Moreover, the preoccupation with the Araucanas and autochthonous groups from Tierra del Fuego represents Nguillatún's decision to subscribe to an indigenous aesthetic programme. In other words, the preference for homegrown cultural production and the inclusion of these "grupos raciales que nos pertenecen de hecho" (racial groups that in fact belong to us) led Nguillatún to conveniently include them in their idea of the 'Chilean nation' although it was most likely that the group itself did not include any members of indigenous descent. ${ }^{58}$

55 "Y como en otra ocasión se nos tachó de europeizamiento y servilidad por el simple hecho de citar, en apoyo de nuestras concepciones personales, algunas teorías y fórmulas artísticas triunfantes en Europa, nada más justo para descartar todo posible nuevo mal entendido, que empecemos ahora al revés de como iniciamos entonces nuestro movimiento. Esa otra manera de hacerlo es recurrir a nuestra raza.” [Anon.]: “Nuestro programa: 'Revista Nguillatún”, p. 149. 56 'Antipode' is used here in a geographical sense, highlighting the opposite hemispheres of Europe and South America.

57 [Anon.]: “Nuestro programa: 'Revista Nguillatún””, p. 149.

58 Vicky Unruh has discussed European vanguardism's obsession with the primitive and supported Marianna Torgovnick's idea that European ideas on the primitive and cultural relativism were based primarily on stereotypes. This is despite James Clifford's argument that the primitivist and ethnographic turn in the avant-garde allowed for a cultural relativism that made Europeans question their own culture (p. 139). As Unruh writes, the case in Latin America was different - it is as if living in the New World allowed the white criollo or mestizo artist access to the 'primitive' in landscape, language, culture - even though these individuals may have no experience with the cultures they wrote about: "In this spirit, the American texts of the vanguards present their vernacular material not as something foreign and remote but rather as palpable experience that might serve as resource material for a new Latin American art” (p. 140). 
Although Nguillatun's proclamation did not directly just emulate Futurism, the group demonstrated why many avant-garde groups in Latin America decided to go 'local', so to speak, to avoid being labelled copycats. In fact, their manifesto's second point was to study avant-garde forms such as Symbolism, Impressionism, Cubism and Expressionism, Nunism and Paroxysm as well as Futurism. The point of this ideological 'rainbow' character was to created a bridge from Chile's atmósfera criolla to a new creative spirit. ${ }^{59}$ Italian Futurism, centred almost 12,000 kilometres away in Italy, would be influential, but peripheral to their own aesthetic programme. Nguillatún serves as an example of how Latin American avant-garde groups sought to emulate certain Futurist genres (for example, the manifesto), to examine the peculiarities of their own society. As it happened, Nguillatún issued only one programmatic, manifesto-like publication: the single issue of the magazine Nguillatún.

In contrast to Nguillatún's failure in creating an indigenista-based national avant-garde, there was one publication in the highlands of southern Peru that actually achieved this goal. The art group Orkopata published Boletin Titikaka in the city of Puno between 1926 and 1930. The Peralta brothers, Gamaliel Churata ${ }^{60}$ (pseudonym of Arturo Peralta, 1897-1969) and Alejandro Peralta (1899-1973), directed the magazine, which was initially set up to publicize the activities of the recently founded Titikaka Press. The magazine was at once literary and political and became the vocero, or voice, of the Orkopata group's indigenista programme of Peruvian nation-building. ${ }^{61}$ Orkopata, an Aymara and Quechua name, is composed of two words: 'orko' means male, as well as hill or mountain, and 'pata', means a high place in both languages. Orkopata is also one of the highest hills that surrounds Puno. ${ }^{62}$ By writing from Puno, a city with a large Aymara and Quechua indigenous population located at 3,800 meters in the Peruvian altiplano, the Peralta brothers made a statement on the importance of the nation's provinces as sources of culture, labour and agriculture upon which Peru's admin-

59 [Anon.]: “Nuestro programa: 'Revista Nguillatún’”, p. 150.

60 Unruh, in Latin American Vanguards, highlights the double-rôle of Gamaliel Churata as_author/ethnographer who collected ethnographic materials from the indigenous cultures of Puno, Peru and Bolivia. Monasterios, in "Unexpected (And Perhaps Unwanted) Revisionisms”, reports on his cultural counter-offensive from Puno, which he coined 'vanguardismo del Titikaka'.

61 The publication consisted of 34 issues that were released monthly, and the first 33 issues were released on time (August 1926 - August 1929). The last one, a special issue dedicated to José Carlos Mariátegui, was delayed and published only in August 1930. See Zevallos Aguilar: "Indigenismo y nación”, p. 23. For more on indigenismo see also Lauer: Andes imaginarios: Discursos del indigenismo.

62 Zevallos Aguilar: "Indigenismo y nación”, p. 23. 
istrative centre of Lima relied. The two brothers suffered for their political views, and Churata had to live a significant part of his life (1932-1964) in exile in Bolivia. ${ }^{63}$

For the purpose of this essay, it is not only pertinent to analyse Churata's avant-garde promotion of indigenismo, but how he used poetic forms such as linguistic play in the manner of the Futurist parole-in-libertà to revitalize indigenous Andean languages in print. As Vicky Unruh states:

This magazine promoted indigenist orthography with the goal of making written Spanish appear visually more like a phonetic transcription of Quechua and labelled such experiments with alternative spellings such as "nwestra ortografía bangwardista" (for "nuestra ortografía vanguardista") and "indoameriqana” (for "indoamericana”). ${ }^{64}$

The group made significant choices in the privileging of indigenous languages, or, when possible, a specifically indigenous re-fashioning of the Castilian idiom. Churata wanted to rescue the Quechua and Aymara languages and engage in multilingual word-play. In fact, Churata experimented with a type of parole in libertà with his epic El pez de oro (The Golden Fish, 1957), which he began around 1907 when he was still a child. The fact that Churata decided to lead an avant-garde movement straight from the altiplano of Puno, a 'vanguardismo del Titikaka', was identified by Luis Alberto Sánchez as one of the "most curious and insolent gestures of Peruvian literature." 65 Although Churata belonged to Mariátegui's generation, his periphery-centred movement was a direct affront to the more 'worldly' Mariátegui, whom Churata accused of feeding on 'literature' while he himself had to 'throw up' the injustices faced by Indians. ${ }^{66}$ In this case, Churata's indictment of Mariátegui is emblematic of the political situation and hostilities between those intellectuals living in the economic, political and cultural centre, Lima, and those who remained attached to peripheral provinces characterized by indigenous peasant life.

63 See Monasterios: “Unexpected (And Perhaps Unwanted) Revisionisms”, p. 317. Monasterios discusses how Churata was excluded from the Peruvian Republic of Letters until recently, when the government asked for forgiveness for its persecution of a valued writer after his death, p. 320. 64 Unruh: Latin American Vanguards, p. 226.

65 “[...] el hecho más curioso e insólito de la literatura del Perú”. Monasterios: "Unexpected (And Perhaps Unwanted) Revisionisms”, p. 317.

66 Monasterios: “Unexpected (And Perhaps Unwanted) Revisionisms”, p. 325. She compares Churata with the Bolivian author Arturo Borda because "like Churata, he also 'vomited' indignation." 


\section{Futurist themes in Peruvian avant-garde poetry}

As Filippo Tommaso Marinetti declared in La fondazione e manifesto del futurismo (The Foundation and Manifesto of Futurism, 1909), the Futurists wished "to sing the praises of the man behind the steering wheel" ${ }^{67}$ and to promote the speed and violent frenzy of contemporary life. This was also true of avant-garde poetry in Latin America, which exalted technology and dynamism of movement, and at times combined them with more social indigenista themes. In this section, my analysis of Peruvian avant-garde poets such as César Atahualpa Rodríguez (1889-1972), Mario Chabes (1903-1981), and Juan Parra del Riego (1894-1925) will call attention to their use of Futurist themes, especially their fondness of technology as the modern means of transportation (train, automobile and aeroplane). In particular, I am interested in how these authors combined these motifs with indigenous or 'American' tropes, such as the Andean landscape, archetypal characters such as the heroic Indian and the life of provincial-city dwellers.

César Atahualpa Rodríguez published in the magazine Anunciación (1915) Futurist poems such as "A toda velocidad" (At Full Velocity, 1915), which captures the sensation of a car's movement albeit in an Andean landscape:

\author{
El automóvil pasa... \\ fuga inquieta una liebre \\ el sol como una brasa \\ dora como un orfebre \\ Una iglesia, una plaza, \\ la campiña, el pesebre \\ fugan tras una casa \\ La brisa está con fiebre. ${ }^{68}$
}

\author{
The car passes \\ A worried hare escapes \\ the sun like embers \\ shines like a goldsmith \\ A church, a town square, \\ the countryside, the manger \\ escape behind a house \\ The breeze has fever.
}

The poem centres on the car's dynamic movement and the sensory experience produced by watching the landscape go by. The driver's or passenger's perceptions of Nature reveal the frightening force of the car's motion. Rodríguez reconciles the automobile's movement with images of traditions, landscapes and people. ${ }^{69}$ For Rodríguez, the car allows the driver to escape from a mundane life

67 "The Foundation and Manifesto of Futurism", in Critical Writings, p. 13.

68 Atahualpa Rodríguez: "Arequipa”, in Pantigoso: Prismas y poliedros, p. 81.

69 Pantigoso quotes Abraham Valdelomar's notes on this poem at length and calls the poem "esencialmente descriptiva sin dejar de ser substancialmente subjetiva" (essentially descriptive but also substantially subjective). Pantigoso: Prismas y poliedros, p. 79. 
centred on the church and the town square. The same sentiment emerges again in his poem "Arequipa” (1914), named after his native city and published in Cien poemas (One-hundred Poems, 1914):

$\begin{array}{ll}\begin{array}{l}\text { Doctores, más doctores; cabezas, } \\ \text { chicherías, } \\ \text { neurastenias, mendigos, graves hipocon- } \\ \text { drías, } \\ \text { señoritas rurales que visten al figurín... }\end{array} & \begin{array}{l}\text { Doctors, and more doctors; heads; chicha } \\ \text { bars } \\ \text { nervous excitabilities, beggars, intense } \\ \text { hypochondriacs } \\ \text { rural young women who dress smartly. }\end{array} \\ \begin{array}{l}\text { Y en medio de todo esto, asustando a la } \\ \text { gente } \\ \text { pasa vociferando el automóvil, de repente, } \\ \text { como una rana negra que devora el } \\ \text { confín. }\end{array} & \begin{array}{l}\text { And in-between all of this, scaring the } \\ \text { people, } \\ \text { the automobile passes shouting, suddenly, } \\ \text { like a black frog who devours the end in } \\ \text { sight. }\end{array}\end{array}$

In the poem above, the automobile also zooms past Arequipa's everyday boredom and humdrum existence. In "A toda velocidad", the automobile almost flies by; the driver or passenger takes a slow pan over the landscape as if in a motion picture. In "Arequipa", the car startles those poor souls it leaves behind. Arequipa's mundane humanity suffers from the jitters ("neurastenias"), beggars ("mendigos"), fake illnesses of all sorts ("graves hipocondrías"), drunkenness - after the night at the chichería - doctors and country girls dressed according to the latest fashions. The car changes the landscape; it deafens the people and scares them with its sudden shouts "like a frog who devours the end in sight" ("como una rana negra que devora el confín").

The panning effect present in "A toda velocidad" is reminiscent of FF. SS. 89. Direttissimo (High-Speed Bullet Train No. 89, 1934) by the Sicilian Futurist Adele Gloria (1910-1984), whose passenger, looking out the express train window, sees a stream of advertisements for chocolate and purgatives speed by: "To look out the window / is to browse through a souvenir series / of colour postcards / at the speed / of who knows how many kilometres per hour." ${ }^{\prime 0}$ While in Peru, Rodríguez wrote about a town full of people who would rather have been elsewhere, Gloria Adele's narrator sitting in a moving train gazes at advertising in a series of postcards or flip-book type of pictures, a typical product of modernity. The speed of the express train changes the rider's view of the landscape; the same happens to the driver observing the Arequipa landscape. Whereas Adele Gloria's rider's view of advertisements at top speed complement the image of an

70 Gloria: “Express Train No. 89 (1934)”, pp. 420-422. 
Italian industrial modernity, in Rodríguez's “Arequipa” and "A toda velocidad” the driver faces only the pettiness of the Andean provincial landscape. Likewise, the landscape changes when viewed from the driver's or train passenger's perspective and blends together like a collage. For Gloria Adele's narrator, the landscape is perceived as a series of advertisements that turn into a motion picture; for Rodríguez's poetic voices, the landscapes offset each other like a series of interchangeable actors.

There were other poets who equated trains and transportation technology with social progress or decline in Peru. Yet, some poets used technology to focus on those it would never have an impact on. Mario Chabes (1903-1981), another Arequipa-born poet, worked with both avant-garde and indigenista motifs, for example in his book of poems, Ccoca (1926). In contrast to Rodríguez's narrators who, sitting in a train, let the landscape pass by, Chabes's passenger chases after the train in his poem "Tren".

Tren

Pu, puú...

Mi corazón se va tras ella. ${ }^{71}$
Train

Pu, puuuu.....

My heart goes after her.

In his poem "Ccoca”, the train completely bypasses the Indian who relies on Coca chewing to accomplish his trek through the Andean mountains on foot:

Ccoca

Chacchando, el indio salva distancias grandiosas, escala millaradas de metros, sin fatiga alguna, dominador del Ande, héroe de la Naturaleza.

Chacchando, descansa en el umbral de la noche o de la muerte.

Tristeza o alegría, ahí está la "chuspa“. Con ella ofrece al sol, a la amarga memoria de los idos y al porvenir, como cuando llega a la pasccana, meta o reposo.

Yo, indio, del Perú, qué para ofrecerte, padre, sino estas hojas de ccoca? ${ }^{72}$
Coca

Chewing along, the Indian goes grand distances, climbs thousands of meters without any fatigue, dominator of the Andes, hero of Nature.

Chewing along, he rests in the night's or death's hallway.

Sadness or happiness, there is the pouch. With it he makes offerings to the sun, to the bitter memory of the bygone days and those about to come, like when he arrives at the wayside inn to take a break.

I, a Peruvian Indian, what can I offer you, father, except for these coca leaves?

71 Chabes: “Tren”, in Ortiz Canseco: Poesía peruana 1921-1931: Vanguardia + indigenismo + tradición, p. 69. 
In the juxtaposition of the indigenous motifs and the climbing the Andean mountains on foot with the technological advances and motion perpetuated by “Train”, Chabes comments on his idea of true human heroism, that of the Indian, against Western technology and its emblem, the train. While the latter relies on the onomatopoeic "pu, puú" of the trains whistle, the sound of coca chewing, this chacchando, typifies the Indian's long-distance trek on foot as a "dominator of the Andes" and a "hero of nature". In the same book of poems, we the find altiplano life featuring in "El Mamani”, set near Lake Titicaca, yet we can also discover a eulogy to transportation technology in "Vigilia del garaje" (Garage's Vigil), in which Ford cars "snore" (roncan) at dawn.

Of course, Italian Futurists were likewise obsessed with transportation technology and machinery. ${ }^{72}$ As Chabes's and Rodríguez's glorifying poems have exemplified, Peruvian avant-garde poets would also follow this trend. There were others who would employ similar themes including Juan Luis Velázquez (19031970), who lived in exile in Spain and later in Mexico, due to his Marxist leanings. A good example is his "La locomotora - loca" (The Locomotive - Mad) in his book El perfil del frente (Profile from the Front, 1924):

\author{
La locomotora - loca \\ deshálase (sic) en gemidos \\ por el despoblado sin fin \\ de los horizontes vacíos. \\ El Sol hecho candela \\ en este horno de siglos \\ seca y tuesta y quema \\ y ciega, los ojos de vidrio. \\ La locomotora refrénase \\ y a la luz guasquea un silbido. \\ Y en la estación estéril \\ donde no brota sembrío \\ nadie sube, nadie baja. \\ Y del torturante cilicio \\ escapa la locomotora y a la luz \\ guasquea otro silbido. ${ }^{74}$
}

\author{
The locomotive - crazy, \\ rushes in spurts and wails \\ through the no man's land without an end \\ towards empty horizons. \\ The sun spews out a fire \\ in this oven of centuries, \\ it dries and toasts and burns \\ and blinds, glass eyes. \\ The locomotive brakes \\ and at the signal light a whistle squeals. \\ And in the sterile station \\ where no weeds sprout \\ nobody gets on, nobody gets off. \\ And from the torturous penitence \\ the locomotive escapes and sends another \\ whistle to the signal light.
}

72 On the full spectrum of Futurist macchinolatria, see Berghaus: Futurism and the Technological Imagination.

73 Velázquez: "La locomotora - loca”, in Ortiz Canseco: Poesía peruana 1921-1931: Vanguardia + indigenismo + tradición, p. 252. 
In contrast to Rodríguez' and Adele Gloria's poems, technology - here: the train is the subject of study, rather than the landscape itself. Velázquez's poem features a locomotive that whizzes and squeals as it moves through an endless and timeless landscape. It is as if, in the American hemisphere, technology fails to have an effect on the landscape. Even though the train passes through town, there is no opportunity for passengers to arrive or depart. Life continues as always. For the American, it is a life full of injustice with no opportunity for travel.

Another admirer of locomotives was Juan Parra del Riego, who travelled to Paris and met European avant-garde artists before moving to Uruguay, marrying there and dying of tuberculosis at an early age. Despite his short life, or perhaps because of his youthful fervour, his poems vary from indigenous themes to tributes to technology. He explored the Peruvian landscape in "Los vientos del Perú", (The Winds of Peru, 1925) which contains a description of the stormy Peruvian winds, a declaration of love for Walt Whitman and an homage to technology. This poem, as well as the title of his book from which it came, Himnos del cielo y de los ferrocarriles (Hymn to the Heavens and to Locomotives, 1925), displays an almost religious reverence towards the train. Within its pages, we find the paean, "Al motor maravilloso" (To the Marvellous Motor), which begins:

Yo que canté un día

la belleza violenta y la alegría

de las locomotoras y de los aeroplanos,

qué serpentina loca le lanzaré hoy al

mundo

para cantar tu arcano

tus vivos cilindros sonámbulos, tu fuego

profundo

¡oh, tú el motor oculto de mi alma y de mis manos! 75
I who sung one day

of the beautiful violence and happiness

of the trains and the aeroplanes

What a colourful and crazy streamer will I

throw today to the world

to sing of your mystery

your lively somnambulistic cylinders, your deep fire

oh! you the mysterious motor of my soul

and of my hands.

Mario Chabes's melancholic "puu puuu” train ode establishes the narrator's longing for it - "mi corazón va tras ella" (my heart goes after it) - and here Juan Parra del Riego literally pries open the engine to express his love for the "cylinders". For, after all, he used to sing about his love for the train, but later in the poem, the poetic voice continues his ode for the "human motor: you are the only

74 Parra del Riego: “Al motor maravilloso”, in Ortiz Canseco: Poesía peruana 1921-1931: Vanguardia + indigenismo + tradición, p. 169. 
marvel in this painful world" that gives him hope, energy and joy in life. ${ }^{75}$ Hence in both poems the tribute ends up not towards the machine, but to the body, the heart, the life force. Parra del Riego's poem also recalls the style present in Canzone del Petrolio (Petroleum Song, 1941) by the Italian Futurist Maria Goretti (1907-2001):

Mud cement sand / the drill bores / sinks inseminates / bites crushes tears / the violated earth screams / but now now / the living blood / gushes / rises / rushes towards the sky / elongated spurt / And sings / I sing! with joy / with freedom / Listen listen Man! / Look at me / I am beautiful / my body is glistening / a black dancer / a single scream / a long spurt screaming / toward the azureness. ${ }^{76}$

Both Parra del Riego and Goretti make an analogy between the machine as a body or the body as a machine. "Al motor maravilloso" praises the body, and Goretti's poem humanizes the machine; it transforms it into a "beautiful" "black dancer", screaming, singing with "joy" and "freedom". ${ }^{77}$

Studies of motion and dynamism, as well as technological advances in transportation, were often the themes in Italian Futurist poetry. ${ }^{78}$ The onomatopoeic "Tuftum, tuftum, tuftum" that mimics the train's sound and movement in Adele Gloria's "High-Speed Bullet Train No. 89" mirrors the motion replicated by painters such as Umberto Boccioni, whose Dynamism of a Cyclist (1913) threatens to explode on the canvas. Futurist painter Benedetta Cappa (1897-1977) also cap-

75 "Motor humano: tú eres / la única maravilla de este mundo doloroso". Parra del Riego: "Al motor maravilloso," in Ortiz Canseco: Poesía peruana 1921-1931: Vanguardia + indigenismo + tradición, pp. 169-170.

76 Goretti: "Petroleum Song”, in Rainey, Poggi, and Wittman: Futurism: An Anthology, pp. 476479. Goretti wrote La donna e il futurismo (Women and Futurism, 1941). See biographical notes in Rainey, Poggi, and Wittman: Futurism: An Anthology, p. 512, and Bello Minciacchi: "La concezione della donna tra futurismo e fascismo: La proposta della futurista Maria Goretti."

77 In Goretti's case, Laura Whitman has argued that "Petroleum Song” represents an "inner colonization" of the Italian territory through the transplantation of immigrants from other parts of Italy as well as industry. To Whitman, the dynamism here is almost static and the image of machinery serves to construct an Italian Empire (p. 415). Similarly, this preoccupation with technology by Peruvian poets is also an attempt to equate technological innovation with the nation's progress.

78 Gloria: “Express Train No. 89”, in Rainey, Poggi, and Wittman: Futurism: An Anthology, pp. 421-422. According to the editors' notes on Adele's poem, titled in Italian "FF. SS.'89" (after Ferrovia dello Stato), the train motif points to Futurism's particular "lyrical obsession with matter" and coincides with the publication of the "Technical Manifesto of Futurist Literature" (May 11, 1912) which equates the freedom afforded by aviation and transportation technology to a claim for linguistic freedom. See Santi Correnti's Il futurismo in Sicilia e la poetessa catanese Adele Gloria as well as Rainey, Poggi, and Wittman: Futurism: An Anthology, p. 568. 
tured the train's dynamism in her oil and collage painting, Luci + rumori di un treno notturno (Light + Sounds of A Night Train, 1924). Years earlier, Giacomo Balla painted his geometric and dynamic Velocità d'automobile (Velocity of an automobile, 1913) and later practitioners of aeropittura (paintings inspired by flight) painted bird's eye-views as well as motions of flight. Likewise, Gerardo Dottori's Sala delle realizzazioni (Hall of Achievements, 1932) at the Exhibition of the Fascist Revolution decorated the hall with the greatest feats of aviation history, such as “Chilometri volati 1930” (Kilometers Flown, 1930). These contrast to the poems of war technology from the first phase of Futurism, for example Enrico Cavacchioli's “Il siluro" (Missile, 1914) and Luciano Folgore’s "Il sottomarino" (The Submarine, 1912) which praise the technology of War. ${ }^{79}$

The interest in aviation amongst Italian aeropittura practitioners had an equivalent in Peruvian poets such as Daniel Ruzo (Lima 1900-1991), who also eulogized flight. His poem "El vuelo" (Flight), published in Madrigales (Madrigals, 1921), honours aircraft technology - breaking the airplane down into specific sections. ${ }^{80}$ His bird's mechanical body eagerly awaits to take off and look down on the landscape below:

Al son del motor rudo que zumba, la aeronave trepida entre sus alas cual si otease la altura; y ardiente y anhleante [sic] su corazón, en suave carrera, se adelanta por la fresca llanura.
To the sound of the crude motor that buzzes, the airship vibrates between its wings, scanning the horizon from above; and its heart, ardent and longing, in a soft run, speeds along the fresh grassland.

Ruzo's poem reflects the shift in fascination from automobile to aviation technology. The mechanical bird speeds over the runway eager for altitude and "ágil se inclina” (nimbly it ascends), "alza la popa leve y va elevándose” (it lifts its stern and begins to ascend). It is almost as if the 'bird' cannot wait to fly. It is an "águila portadora del fuego, / en geométricas líneas sobre el paisaje asciende” (an eagle carrier of the fire, / in geometric lines it ascends). Its movements upwards are controlled in Cubo-Futurist geometric lines. "Silenciando su fiel motor" (silencing its faithful motor), it rests at ease in the air until finally, "en suaves círculos elegantes desciende" (in soft elegant circles it descends). Even though the plane returns to its point of departure on the "fresh grassland", Ruzo succeeds in glorifying the plane's engine power and the beauty of its flight. In as sense, Ruzo's

79 Reference taken from "Notes" in Rainey, Poggi, and Wittman: Futurism: An Anthology, p. 569. 80 Ruzo: "El vuelo" in Ortiz Canseco: Poesía peruana 1921-1931: Vanguardia + indigenismo + tradición, p. 224. 
poem is a perfect textual example of aeropoesia, a genre that emerged in Italy later in the 1930s. Its aesthetics were outlined by Elemo D’Avila and Giuseppe Isani in the Primo manifesto futurista di aeropoesia (First Manifesto of Aeropoetry, 1931) and F. T. Marinetti in L'aeropoesia: Manifesto futurista ai poeti e agli aviatori (Aeropoetry: Futurist Manifesto to the Poets and Aviators, 1931).

In short, most of the Peruvian poets used dynamism and honoured technology while still remaining interested in describing the Peruvian landscape and its people. At the same time, while the shiny tools of transportation technology (trains, aeroplanes and automobiles) made an appearance also in the peripheries of the American continent, the left the majority of those struggling to survive on the social margins behind.

\section{Conclusion}

Indigenismo and Futurism seem at first to have little to say to each other except in the tangible experience of Mariátegui, who wrote about the Futurists, lived in Italy and included Marinetti's manifestos in Amauta despite his loathing of what he considered to be Marinetti's Fascism.

However, as this essay has revealed, Latin American poets and editors used Futurist and other avant-garde techniques to make their own claims about social justice and to honour indigenous traditions on the American continent. While all of these projects saw the 'autochtone' and the 'national' as a viable platform from which to promote 'New World' or 'American' art, it was mainly artists with a criollo and mestizo background who undertook these attempts for the benefit of their own culture and class. Even Titikaka's work from the city of Puno was made for a reading audience in the capital Lima, as Zevallos Aguilar demonstrated. Of course, Mariátegui's and Churata's noble attempts, while lacking the true voice of the Indian, did allow for Quechua and Aymara to permeate the dominion of an élite group who promoted cultural innovation, often relegated and reserved for use of the Castilian language amongst criollos and mestizos.

Mariátegui's focus on indigenismo as well as avant-garde themes in Amauta merits a place besides the work of these poets. His inclusion of poets who amalgamated indigenismo and Italian Futurism made city dwellers, the lettered and cultured, aware of the injustices suffered by those who would not be part of or would be crushed by the technological revolution.

César Atahualpa Rodríguez was a typical example of this trend. He presented the effects of the automobile on both the people it leaves behind in "Arequipa" as it travels to more interesting places. He also described the driver's sensation when speeding through the landscape "a toda velocidad". Mario Chabes repre- 
sented a train that departs without its passenger and focusses our attention on the Indian who walks through the landscape chewing coca leaves, a stimulant that that permits him to complete his daily "heroic" treks up and down the sierra. This view contrasts with the one presented by Juan Parra del Riego, who applies the symbols and sounds of technology to the human body and extols the beauty of the "human motor". Daniel Ruzo is in awe of aviation technology, but still kept in mind that the aeroplane in the end has to return to the grassy field from which it ascended. Likewise, Juan Luis Velázques’s “Locomotora”, in a similar way to Chabes's "puuu”, catches the sounds of the locomotive, but ultimately, its melancholic whistle wails against the emptiness of the land.

In a recent study, Ileana Rodriguez investigated the relationship between the State, culture and 'subalternity'. ${ }^{81}$ Beyond the question of speaking for the subaltern, Mariátegui's project, as well as some of the editorial and poetic attempts that I have examined here, used the marginalized indigenous subjects to theorize on the Amerindios and their state of existence. Perhaps, as a project, it was too theoretical and aimed too much at the cultured élites, who had little practical experience of life on the margins of society. However, while we can criticize the limitations of such artistic projects, we can also applaud the attempts at including the indigenous populations in the creation of an essentially 'New World' culture.

Ultimately, the avant-garde indigenistas and futuristas who collaborated with Amauta, Boletin Titikaka and Nguillatún functioned as an isthmus between the indigenous peoples of the highlands and the coastal mestizos. They provided a fragile, yet important connection between two distinct social realities. While this perspective leaves out the rôle of Afro-Peruvians, Chinese migrants and others who so visibly contributed to the economic, intellectual, cultural and social development of South American nations, we can revisit the Futurists' preoccupation with a global future as a sign that they sought to move beyond an insular position. Amauta is an example of this: the magazine attempted to bring together

81 'Subalternity' (from Latin subalternus, 'next below') refers in Postcolonialist Studies to populations that are socially and politically positioned outside of the 'hegemonic' power structure. Subalterns entered intellectual discourse through the work of the Subaltern Studies Group who mostly worked on the social and political histories of South Asia. Rodríguez examines the relationship between South Asian "Subaltern Studies' and Latin American Studies in her two edited volumes, The Latin American Subaltern Reader (2001) and Convergencia de tiempos: Estudios subalternos / contextos latinoamericanos: Estado, cultura, subalternidad (Convergence of Times: Studies on Subaltern Contexts in Latin America. State, Culture, Subalternity, 2001). These volumes document a trend in the North American academy that seeks to intertwine South Asian and Latin American contexts. 
the European and Latin American avant-gardes as it promoted social justice for marginalized communities both in Latin America and in the rest of the world.

While it is beyond the scope of this essay, it is important to note that there was also a turn in Italian Futurism towards the 'autochtone' and the primitive, ${ }^{82}$ often rooted in folk traditions and the culture of populations living on the margins of society. Thus, the autochthonous became an important part of Italian Futurism. For example, Giacomo Giardina, a Sicilian shepherd called a "poeta pecoraio" (shepherd poet) wrote his Futurist poetry in a dialect of the mountainous Godrano region. ${ }^{83}$ Fortunato Depero used the folk traditions of his native Trento region in the workshop productions of his Casa d'arte futurista. ${ }^{84}$ On Capri, artists used indigenous architectural motifs and incorporated them into Futurism. ${ }^{85}$ The same can be said for Sardinia, Apulia and Calabria. ${ }^{86}$ In a return to linguistic freedom, artists from Naples used the local dialect to create Futurist works. Neapolitan Futurists used dialect in their poetry (Cangiullo) and combined their anti-Fascist struggle with the creation of fine art (see the Union of Activist Destructivists and the Circumvisionists), a highly difficult and dangerous activity under the circumstances of Mussolini's dictatorship. ${ }^{87}$

Perhaps it was Futurism's promise of rupture with the establishment, whether in aesthetics, language or politics, that inspired these poets and artists to take the leap, in the Futurist mode, at full speed and write in non-standard Italian and celebrate the culture of the provinces, the dialects and languages of the peripheries. As such, I hope that more scholarly attention will turn to these understudied aspects of Futurism. Like the avant-garde indios and mestizos of the Andes and of Lima, they sought to renew their language, fight against oppression and celebrate their local landscape and customs.

82 I am grateful to Günter Berghaus for his assistance in referring me to this turn to the 'autochtone' and the primitive in Italian Futurism.

83 See Russo: Giacomo Giardina: Il poeta bucolico-futurista.

84 See Scudiero: Casa d'arte futurista Depero.

85 See Sabatino: "Tabula rasa or Hybridity? Primitivism and the Vernacular in Futurist and Rationalist Architecture."

86 For Sardinia see Maritano: Futurismo in Sardegna: L'episodio sardo alla fine degli anni Trenta and Barbato and Masi: Aspetti del futurismo in Italia e in Sardegna. For Futurism in Apulia see Pasquale Sorrenti's La Puglia e i suoi poeti dialettali: Antologia vernacola pugliese dalle origini and his Il futurismo pugliese: Contributo ad una storia del futurismo. Futurism in Calabria has been the subject of several studies by Vittorio Cappelli.

87 See Berghaus: Futurism and Politics, pp. 279-281. 


\section{Bibliography}

[Anon.]: “Nuestro programa: 'Revista Nguillatún'.” Revista Nguillatún 1 (6 December 1924):

1. Reprinted in Nelson Osorio Tejeda, ed.: Manifiestos, proclamas y polémicas de la vanguardia literaria hispanoamericana. Caracas: Biblioteca Ayacucho, 1988. 149-151.

Ayala, José Luis: “Mariátegui, el fascismo y futurismo.” Boletín Casa Museo José Carlos Mariátegui 14:2 (April-June 2016): 9-11.

Bann, Stephen, ed.: The Tradition of Constructivism. New York: Da Capo Press, 1974.

Barbato, Chiara, and Alessandro Masi, eds.: Aspetti del futurismo in Italia e in Sardegna. Roma: Aracne, 2011.

Bello Minciacchi, Cecilia: "La concezione della donna tra futurismo e fascismo: La proposta della futurista Maria Goretti." C. Bello Minciacchi: Scrittrici della prima avanguardia: Concezione, caratteri e testimonianze del femminile nel futurismo. Firenze: Le Lettere, 2012. 173-208.

Berghaus, Günter: Futurism and Politics: Between Anarchist Rebellion and Fascist Reaction, 1909-1944. Providence/RI: Berghahn Books, 1996.

Berghaus, Günter, ed.: Futurism and the Technological Imagination. Amsterdam: Rodopi, 2009. Cappelli, Vittorio: "Tra analfabeti e futuristi: La scuola e gli intellettuali in Calabria durante il fascismo." Daedalus 3 (1989): 41-73.

Cappelli, Vittorio: “Tra analfabetismo e futurismo." Vittorio Cappelli, and Luciano Caruso, eds.: Calabria futurista: Documenti, immagini, opere. Soveria Mannelli (CZ): Rubbettino, 1997. 7-14.

Cappelli, Vittorio: "Tra analfabetismo e futurismo: La partecipazione calabrese al movimento d'avanguardia." Vittorio Cappelli, ed.: Calabria futurista 1909-1943. Atti del convegno "Perifuturismo: Il futurismo corre ai lati tra i vulcani i terremoti e il mare", tenuto ad Arcavacata: Università della Calabria, 16-20 novembre 2009. Soveria Mannelli (CZ): Rubbettino, 2009. 39-46.

Casetta, Giovanni: "Il problema indigeno dalla tradizione alla modernità: José Carlos Mariátegui.” Nova americana 3 (1980):101-140.

Castrillón Vizcarra, Alfonso: “Iconografía de la revista 'Amauta': Crítica y gusto en José Carlos Mariátegui." Illapa 3:3 (December 2006): 35-44.

Castrillón Vizcarra, Alfonso: “José Carlos Mariátegui, crítico de arte." Cuadernos de reflexión y crítica 4:6 (January-June 1993): 260-266.

Cavacchioli, Enrico: Cavalcando il sole. Milan: Edizione futuriste di “Poesia”, 1914.

Contarini, Silvia: "Valentine de Saint-Point: A Futurist Woman?” International Yearbook of Futurism Studies. 5 (2015): 87-110.

Correnti, Santi: Il futurismo in Sicilia e la poetess a catanese Adele Gloria. Catania: CUECM, 1990.

Farnsworth, Beatrice: Aleksandra Kollontai: Socialism, Feminism, and the Bolshevik Revolution. Stanford/CA: Stanford University Press, 1980.

Folgore, Luciano: Il canto dei motori. Milan: Edizione futuriste di “Poesia”, 1912.

Gallo, Rubén: "Wireless Modernity: Mexican Estridentistas, Italian and Russian Futurism.” International Yearbook of Futurism Studies 2 (2012): 141-170.

Gloria, Adele: “Express Train No. 89 (1934).” Lawrence Rainey, Christine Poggi, and Laura Wittman, eds.: Futurism: An Anthology. New Haven/CT: Yale University Press, 2009. 420-422.

Simpson, John Andrew, and Edmund S. C. Weiner, eds.: The Oxford English Dictionary. Oxford: Clarendon Press, 1989. 
Kollontai, Alexandra: Love of Worker Bees. Ed. by Cathy Porter. Chicago/IL: Academy, 2004. Krzywkowski, Isabelle: “'Amauta', L'europe et les avant-gardes”. Sascha Bru, et al., eds.: Europa! Europa? The Avant-Garde, Modernism and the Fate of a Continent. Berlin: De Gruyter, 2009. 434-45.

Larson, Brooke: Trials of Nation Making: Liberalism, Race, and Ethnicity in the Andes, 1810-1910. Cambridge: Cambridge University Press, 2004.

Lauer, Mirko: Andes imaginarios: Discursos del indigenismo. Vol. 2. Cusco: Centro de Estudios Rurales Andinos Bartolomé de las Casas, 1997.

Mariátegui, José Carlos: “Aspectos viejos y nuevos del futurismo.” J.C. Mariátegui: Ediciones populares de las obras completas. Vol. 15. Cartas de Italia. Lima: Amauta, 1969. 220-223.

Mariátegui, José Carlos: "Balance del suprarrealismo." J.C. Mariátegui: Ediciones populares de las obras completas. Vol. 6. El artista y la época. Lima: Amauta, 1959. 46-52. English translation “A Balance Sheet on Surrealism.” José Carlos Mariátegui: An Anthology. Ed. by Harry E. Vanden, and Marc Becker. New York: Monthly Review Press, 2011. 415-421.

Mariátegui, José Carlos: "Nativismo e indigenismo en la literatura americana." La pluma (Montevideo) 1 (August 1927): 42-43. Revised as "El proceso de la literatura. XVII. Las corrientes de hoy. El indigenismo." J.C. Mariátegui: Siete ensayos de interpretación de la realidad peruana. Caracas: Biblioteca Ayacucho, 2007. 276-290.

Mariátegui, José Carlos: “Giovanni Papini.” Variedades (Lima) 19:820 (17 November 1923). Reprinted in J.C. Mariátegui: El alma matinal y otras estaciones del hombre de hoy. Lima: Editora "Amauta", 1950. 137-140..

Mariátegui, José Carlos: “La mujer y la política.” Variedades, 15 March 1924. English translation "Women and Politics." José Carlos Mariátegui: An Anthology. Ed. by Harry E. Vanden, and Marc Becker. New York: Monthly Review Press, 2011. 361-365.

Mariátegui, José Carlos: “La nueva literatura rusa.” J.C. Mariátegui: Ediciones populares de las obras completas. Vol. 6. El artista y la época. Lima: Amauta, 1959. 158-161.

Mariátegui, José Carlos: “Literature on Trial.” J.C. Mariátegui: Seven Interpretive Essays on Peruvian Reality. Trans. Marjory Urquidi. Austin/TX: University of Texas Press, 1971. 182-287.

Mariátegui, José Carlos: “Marinetti y el futurismo.” Variedades (Lima) 20:829 (19 January 1924): 156-158. Reprinted in J.C. Mariátegui: Ediciones populares de las obras completas. Vol. 1. La escena contemporánea. Lima: Amauta, 1976. 140-144.

Mariátegui, José Carlos: “Nativismo e indigenismo en la literatura americana." La pluma (Montevideo) 1 (August 1927): 41-43.

Mariátegui, José Carlos: “Nativismo e indigenismo." Gloria Videla de Rivero, ed.: Direcciones del vanguardismo hispanoamericano: estudios sobre poesía de vanguardia. Documentos. 3rd. ed. Mendoza, República Argentina: Universidad Nacional de Cuyo (EDIUNC), 2011. 295- 298.

Mariátegui, José Carlos: “Pasadismo y futuro.” J.C. Mariátegui: Obras completas populares. Vol. 11. Peruanicemos al Perú. Lima: Amauta, 1970. 29-34.

Mariátegui, José Carlos: “Presentación de 'Amauta'.” Gloria Videla de Rivero, ed.: Direcciones del vanguardismo hispanoamericano: estudios sobre poesía de vanguardia. Documentos. 3rd. ed. Mendoza, República Argentina: Universidad Nacional de Cuyo (EDIUNC), 2011. 298-300.

Marinetti, Filippo Tommaso: “Movimiento futurista.” Amauta 2:10 (December 1927): 29. Marinetti, Filippo Tommaso: "The Foundation and Manifesto of Futurism." F.T. Marinetti: Critical Writings. Ed. by Günter Berghaus. New York: Farrar, Straus and Giroux, 2006. 11-17. 
Maritano, Mario: Futurismo in Sardegna: L'episodio sardo alla fine degli anni trenta. Oristano: S’Alvure, 1993.

Mojarro Romero, Jorge: “Mariátegui y el futurismo italiano." Tonos: Revista electrónica de estudios filológicos. 14 (2007): s.p. < https://www.um.es/tonosdigital/znum14/secciones/ estudios-18-futurismo.htm> (consulted 21 October 2016)

Monasterios, Elizabeth: “Unexpected (And Perhaps Unwanted) Revisionisms: La contramarcha vanguardista de Gamaliel Churata y Arturo Borda.” Modern Language Notes 130:2 (2015): 316-339.

Montenegro, Giovanna: “Futurism in Venezuela: Arturo Uslar Pietri and the Reviews 'Índice’ and 'válvula'." International Yearbook of Futurism Studies 2 (2012): 286-303.

Ortiz Canseco, Marta, ed.: Poesía peruana 1921-1931: Vanguardia + indigenismo + tradición. Madrid: Iberoamericana: Vervuert; Lima: Librería Sur, 2013.

Osorio Tejeda, Nelson: "Prólogo." N. Osorio Tejeda, ed.: Manifiestos, proclamas y polémicas de la vanguardia literaria hispanoamericana. Caracas: Biblioteca Ayacucho, 1988. IX-XL.

Osorio Tejeda, Nelson: El futurismo y la vanguardia literaria en América Latina. Caracas: Centro de Estudios Latinoamericanos "Rómulo Gallegos”, 1982.

Pantigoso, Manuel: Prismas y poliedros: Ismos de la vanguardia peruana. Lima: Intihuatana, 2011.

Podestá, Bruno, ed.: Mariátegui en Italia. Lima: Biblioteca Amauta, 1981.

Porter, Cathy: Alexandra Kollontai: A Biography. London: Virago, 1980.

Price, Heather: Alexandra Kollontai: Soviet Marxist and Feminist. Canterbury: University of Kent, 1990.

Rainey, Lawrence, Christine Poggi, and Laura Wittman, eds.: Futurism: An Anthology. New Haven/CT: Yale University Press, 2009.

Rodríguez, lleana, and Hamid Dabashi, eds.: Convergencia de tiempos: Estudios subalternos/ contextos latinoamericanos. Estado, cultura, subalternidad. Amsterdam: Rodopi, 2001.

Rodríguez, lleana, ed.: The Latin American Subaltern Studies Reader. Durham/NC: Duke University Press, 2001.

Russo, Antonino ed.: Giacomo Giardina: Il poeta bucolico-futurista. Con poesie inedite in volume, immagini, documenti. Palermo: Istituto Siciliano di Studi Politici ed Economici, 2009.

Sabatino, Michelangelo: "Tabula rasa or Hybridity? Primitivism and the Vernacular in Futurist and Rationalist Architecture." Günter Berghaus, ed.: Futurism and the Technological Imagination. Amsterdam/New York: Rodopi, 2009. 287-314.

Saint-Point, Valentine de: "Manifesto of the Futurist Woman (Response to F.T. Marinetti)." Lawrence Rainey, Christine Poggi, Laura Wittman, eds. Futurism: An Anthology. New Haven: Yale University Press, 2009. 109-113.

Scholz, Lázló: “Julio Walton H.: El aullido de las rameras. Un texto inédito del grupo 'Rosa Náutica'.” L. Scholz: Ensayos sobre la modernidad literaria hispanoamericana. Murcia: Universidad de Murcia, 2000. 173-178.

Schwartz, Jorge: “Perú: Revistas.” J. Schwartz, ed.: Las vanguardias latinoamericanas: Textos programáticos y críticos. 2nd edn México, D.F.: Fondo de Cultura Económica, 2002. 329-333.

Scudiero, Maurizio, ed.: Casa d'arte futurista Depero. Exhibiton catalogue. Bozen: Galerie lles Chances de l'Art, marzo-aprile 1992; Trento: Galleria d'Arte Il Castello, marzo-aprile 1992; Rovereto: Galleria Spazio Arte, marzo-aprile 1992. 
Sorrenti, Pasquale: La Puglia e i suoi poeti dialettali: Antologia vernacola pugliese dalle origini. Bari: De Tullio, 1962.

Sorrenti, Pasquale: Il futurismo pugliese: Contributo ad una storia del futurismo. Bari: Levante, 1992.

Sylvers, Malcolm: “La formación de un revolucionario.” Bruno Podestá, ed.: Mariátegui en Italia. Lima: Empresa Editorial Amauta, 1981. 19-77.

Unruh, Vicky: Latin American Vanguards: The Art of Contentious Encounters. Berkeley/CA: University of California Press, 1994.

Vanden E. Harry and Marc Becker: “Introduction.” Harry E. Vanden, and Marc Becker, eds.: José Carlos Mariátegui: An Anthology. New York: Monthly Review, 2011. 11-61.

Vich, Cynthia M.: Indigenismo de vanguardia en el Perú: Un estudio sobre el "Boletín Titikaka". Lima: Fondo Ed. de la Pontificia Univ. Católica del Perú, 2000.

Videla de Rivero, Gloria: Direcciones de vanguardismo hispanoamericano. Vol. 1. Estudios sobre poesía de vanguardia en la década del veinte. Vol. 2. Documentos. Mendoza: Universidad Nacional de Cuyo, Facultad de Filosofía y Letras, 1990. 2nd edn Pittsburgh/PA: Instituto Internacional de Literatura Iberoamericana, 1994.

Yurkievich, Saúl: “Rosa Náutica, un manifiesto del movimiento de vanguardia chileno." Bulletin de la Faculté des Lettres de Strasbourg 46 (April 1968): 649-55.

Zevallos, Aguilar U. J.: Indigenismo y nación: Los retos a la representación de la subalternidad aymara y quechua en el "Boletín Titikaka” (1926-1930). Lima: Instituto Francés de Estudios Andinos, 2002. 